\title{
NATURALISTIC STUDY ON COMMUNICATION STRATEGY USED BY SIXTH SEMESTER STUDENTS IN MICROTEACHING CLASS OF ENGLISH DEPARTMENT OF MUHAMMADIYAH UNIVERSITY OF SURAKARTA
}

\author{
By \\ Rannisa Elly Fathin \\ Muhammadiyah University Of Surakarta
}

\begin{abstract}
This research aims to describe communication strategy which is used by the sixth semester students in Microteaching class of English Department of Muhammadiyah University of Surakarta. This research is also reference to to minimize the problem which is occured during learning-teaching process. The data of this research is containing of communication strategy used by sith semester students in microteaching class of English Department of Muhammadiyah University of Surakarta. There are three sourcess data of this research, namely: event, informant, and document. The writer used descriptive qualitative to analyze the data. The process of classifying and counting the result of the data used Celce-Murcia taxonomy. The result of the data shows that there are 5 types with thirteen subtypes of communication strategies. Filler is the most dominant type of communication strategy with the percentage $43,90 \%$, while the type that rarely used by the students is message abandonment, rephrsing, and appeal for help with the each percentage is $0,19 \%$.
\end{abstract}

Keywords: Communucation strategies, microteaching

\section{Introduction}

University Muhammadiyah of Surakarta (UMS) belongs to one of several Universities in Surakarta. UMS established on $18^{\text {th }}$ September 1958. Previously, UMS begins from subdivision of Teacher Training and Education faculty of Muhammadiyah University of Jakarta which is established in Surakarta on 1957. Firstly, UMS only has 51 students, 6 employees, and 7 lecturers that become initial fund to build UMS.

Nowadays, UMS has been developed. It becomes famous time to time. The students continously increase every year. The applicants is not only from Surakarta, but comes from many countries in the world. Further, the major in UMS is also developed. Now, UMS has 12 faculties for undergraduate, 10 faculties for post graduate, and 1 faculty for doctoral programme. English becomes global language that is widely learned and must be learned, because English has been internationalized. It can be seen that in every sector of our 
life is nearly surounded by English. Bailey and Savage (1994: vii) in Fauziati (2010: 15) state that "speaking in a second foreign language has often been viewed as the most demanding of the four skills". It is because speaking is the primary way for the people to communicate with other around the world. The goal of language teaching is to develop what Hymes (1972) reffered to as "communicative competence". Hymes coined this term to contrast a communicative view of language and Chomsky"s theory of competence and performance. For Chomsky (1965: 3) in Fauziati state that competence is "the speakerheareres knowledge of his language." Speaker and hearer are defined as those ideal individuals in a completely homogeneous speech community. Hymes ideas about the „communicative competence" were later developed by Canale and Swain in 1980 who introduced a theoritical model of „,communicative competence ${ }^{e e}$. In their concept of communicative competence, knowledge refers to the (conscious or unconscious) knowledge of an individual about language and about other aspects of language use. According to them, there are three types of knowledge: knowledge of underlying grammatical principles, knowledge of how to use language in a social context in order to fulfil communicative functions and knowledge of how to combine utterances and communicative functions with respect to discourse principles.

It was Selinker (1977) who first used the term communicative strategies or strategies of second language communication to refer to one processes that is responsible for producing interlanguage error. He defined communicative strategy as "an identifiable approach by the learner to communicate with native speakers of the target language" (1977: 37) in Fauziati (2010: 167). Fauziati (2010: 168) state that communication strategy is to make up inadequacies they may have in grammatical ability and vocabulary communication strategies also help the learners with participating in and maintaining conversations and improving the quality of communication. According to Fauziati (2010:15) the goal of teaching speaking skill is communicative efficiency. Thus the learners should be able to speak English in foreign language in any situation. Communication strategy is used to facilitate the people to speak. It explained the step how to speak English. Most of someone $\mathrm{s}$ communication strategies develop unconsciously, through assimilation of role models-person we admire and some extend and success experienced in the past (Savignon, 1983: 40). Since English becomes important part in this world, it is better for us to learn English as early as possible. The more grown up the more world develop. It also becomes important requirement in the job competition. In this study, the writer focuses on comunication strategies process which is applied in microteaching class. There are some reasons that should be identifying by 
the writer. First, the writer wants to know what is the type of communication strategies which is used by the students in order to achieve their meaning when they talk talk to the other. Second, to investigate what kind of communication strategies are suitable with Indonesian learners. Based on that, the writer took some previous study related to communication strategy to prove the originality of this research. They are Delamere (1998), Pratiwi (2011), Herawati (2015), Rolitasari (2015), Sari (2015). The research was conducted by Delamere (1998) from Dublin City University resulted that this study indicate that all subjects, irrespective of proficiency, are reliant on communication strategies when they encounter communicative difficulties in L2. The results of the study reveal that the moreadvanced learners do not use more L2-based strategies and are, in fact, entrenched in L1/L3based behaviour. This research aims to identify the strategies of communication Englishspeaking learners when confronted with linguistic dificulties in the French language. The type of this research is qualitative method, especially naturalistic study and using elicitation task for collecting the data. Pratiwi (2011) conducted her research of communication strategy resulted that: a) there are five major types of communication strategies: avoidance or reduction strategies with 3,65\%, achievement or compensatory strategies with $23,59 \%$, stalling time gaining strategies with 58,5\%, self-monitoring strategies with 5,32\% and the last is interactional strategies with $8,97 \%$. b) from five major types communication strategies, stalling or time gaining strategy is the most frequently used. The study is carried out to describe the communication strategies used by students of Speaking III of English Department, Muhammadiyah University of Surakarta. The type of the research is descriptive qualitative method in analyzing the data. The writer used Celce-Murcia framework to analyzed her data. The research of communication strategies was conducted by Herawati (2015) resulted that there are: (1) the respondents use all the type of communication strategies, namely: a) topic avoidance, b) message abandonment, c) paraphrase, d) coinage, e) native language switching, f) miming and g) appeal for assistance, (2) the dominant type of communication strategies used by the respondents is native language switching with the precentage $35.29 \%$. The research aimed at describing 1) the types communication strategies, 2) the dominant type of communication strategies, 3) the functions of communication strategies used by the eight grade students in speaking class at SMP N 1 Surakarta. The research carried out belongs to descriptive qualitative research since it is conducted to describe the findings and used Taronee s framework to analyzed her data.

Research of communication strategies was also conducted by Rolitasari (2015). The result of this study shows that there are five types of communication strategies. The 
frequency of each subtypes of communication strategies namely: message abandonment is 8 , non-linguistic measns is 1 , restructing is 1 , code switching is 19 , retrieval is 14 , fillers is 60 , self repetition is 37 , self-initiated repair is 11 , appeal for help is 10 . The most dominant types of communication strategies used by students in SEGA program is fillers with 37,26\%, and the type of communication strategies rarely used by the students is non-linguistic means and restructuring with $0,62 \%$. The objectives of this study are as follows: 1) to find out the type of Communication Strategies used by students of SEGA program in conversation, 2) to figure out the frequency of each type of communication strategies used by students of SEGA program in conversation, 3) to know the dominant type of communication strategies used by students in speaking session of SEGA program. The study of communication strategy was conducted by Sari (2015) in SEGA programme. The result of data analysis the researcher found 4 types with 10 subtypes of communication strategy that are used by the students in SEGA program UMS. They were, a) Stalling or Time-gaining Strategies: (1) Self Repetition with 25,38\%, (2) Fillers with 41,11\%. b) Interactional Strategies: (1) Appeal for Help with 1,52\% (Indirect) and 7,1\% (Direct), (2) Requests (Repetition) with 1,01\%. c) Achievement or Compensatory Strategies: (1) Retrival with 4,56\%, (2) Code Switching with 7,61\%, (3) Non-Linguistic Means with 2,53\%, (4) Word Coinage with 1,01\%, (5) Restructing with 1,52\%. And the last d) Self Monitoring Strategies: (1) Self Initiated Repair with 6,59. The frequency of each subtypes of communication strategies is as follows: fillers is 81 , self repetition is 50 , code switching is 15 , retrival is 9 , non-linguistics mean is 5 , restructing is 3 , word coinage is 2 , appeal for help (direct is 14 , indirect is 3 ), request: repetition is 2, self initiated repair is 13 . The dominant strategy used by the students is Stalling or Time-gaining strategies with $66,49 \%$ and the lowest precentage is Self Monitoring Strategies with $6,59 \%$. The objectives of the study are as follows: 1) to find out the type of communication strategies, 2) to figure out the frequency of each communication strategies, 3) to know the dominant type of communication strategies used by students in speaking session of Saturday English Gathering (SEGA) Program in University Muhammadiyah Surakarta. Based on the previous above, it shows that communication strategies become a fundamental subject to discuss, hence, the writer choose this subject to discuss deeper. The previous studies above shows that all of the researchers conducted the research about communication strategies used by student to the reference for the better of speaking. It is same with the current study that will be investigated by the researcher, the object of this research is also about communication strategies. But here, in this current study, the writer choose microteaching class as her subject. The reason is because the writer has not found yet 
the previous study which is discuss about microteaching. So, the writer here wants to know and observe what kind of communication strategy used by students in microteaching class. Here, the writer can conclude that this research is original because this research is different from the other researcher. The difference of this research with the previous above is in the type of the research. The writer found that naturalistic study is not something new in communication strategies, but here, the writer do the research to know if there is something different in the communication strategies used by students.

Based on the previous differences, the posisition of current study to conduct a research with the objective is to describe communication strategies. The objective is divided into 3 parts, there are: (1) to know the type of communication strategies, (2) to describe the frequency of communication strategy, and then (3) to identify the domininant type of communication strategies. So, the writer conducted the research about Naturalistic Study on Communication Strategies Used by Sixth Semester Students in Microteaching Class of English Department of Muhammadiyah University of Surakarta 2016 Academic Year.

\section{Research Method}

This research is a naturalistic study of communication strategies used by microteaching students in Muhammadiyah University of Surakarta year 2015/2016. Krashern and Terrell (1983: 71) in Fauziati (2014: 86) claim that naturalistic approach is "for beginners and is designed to help them becomes intermediates. It is expected that students will be able "to communicate with native speaker in the target situation". Natural approach belongs to tradition of language teaching methods based on observation and interpretation. The analyzed this research by using Celce-Murcia framework. This research is conducted in purpose to understand the phenomena of communication strategies employed by microteaching students at sixth semester in University Muhammadiyah of Surakarta. Besides, the writer also identifies the kind of students speaking based on Celce-Murcia taxonomies. Then in the final the writer conducts this research by applying qualitative research method.

Qualitative research uses no statistical analysis. It is inductive in nature; that is, it collects the data through observation and then comes up with a theory to account for the data. According to Lincoln and Denzin (1994: 1) qualitative research is "a field of inquiry in its own right". Qualitative research, broadly defined, means "any kind of research that produces findings not arrived at by means of statistical procedures or other means of 
quantification" (Strauss and Corbin, 1990, p. 17) and instead, the kind of research that produces findings arrived from real-world settings where the "phenomenon of interest unfold naturally" (Patton, 2001, p. 39). Unlike quantitative researchers who seek causal determination, prediction, and generalization of findings, qualitative researchers seek instead illumination, understanding, and extrapolation to similar situations (Hoepfl, 1997). Hence, from the citation above, the writer definetely state that she applied qualitative method in the research, because the data that are taken iclude in kinds of communication strategies employed by each students of microteaching in University Muhammadiyah of Surakarta.

\section{Finding And Discussion}

The writer classified the finding into 3 parts, namely types of communication strategies used by the learner, the frequency of communication strategies, and the dominant type of communication strategies used by sixth semester students in microteaching class of Muhammadiyah University of Surakarta in 2015/2016 academic year.

\subsection{Types of Communication Strategies Used by Students}

Based on the data that has been analyzed by the writer in the form of transcribed conversation, the writer found 5 types with 13 subtypes of communication strategies used by sixth semester students in Microteaching class of English department of Muhammadiyah University of Surakarta.

a. Aoidance and Reduction Strategies

1) Topic Avoidanve

Topic avoidance is strategy which is used to avoid topic areas or concepts which pose language difficulties. The reason of using this strategy is probably because of the lack of knowledge, idea, or vocabulary. Here, the example of topic avoidance:

$\begin{array}{ll}\text { T18 } & \text { : Ok great answer. Give applause for Yunita. Emm anyone } \\ & \text { know what is personal letter in your in your opinion? Can } \\ & \text { you explain in your word in your own word? } \\ \mathrm{S} & \text { : No } \\ \mathrm{T} 18 \quad & \text { : No, oke. And eee have you make a personal letter } \\ & \text { personal letter before? } \\ \mathrm{S} & \text { : Yes, } \\ \mathrm{T} 18 \quad & \text { : Of course because ee like ee students to the teacher and } \\ & \text { the child with the their parents. Ee there is ee from your } \\ & \text { many kind of personal letter maybe there is eee an an } \\ & \text { greeting or ee congratulation but maybe can you can you } \\ \text { mention ee the kind of your kind of some of expression in } \\ \text { personal letter you have have you is or have you make, in }\end{array}$


what what expression. Tell me.. you think your.. emm.. (topic avoidance)

: the example?

2) Message Abandonment

Message abandonment is strategy used by the learners in which the learner begins to talk about concept but feeling unable to continue, stops before reaching their communicative goal.

T4 : Emm.. the last number. Decidely

$\mathrm{S}$ : Decidely

T4 : Ok, thank you. Emm.. I think emm.. that's.. I think enough, emm.. study about narrative text, emm.. any question so far? About... (message abandonment)

$\mathrm{S}:$ No

T4 : The narrative text? No?

b. Achievement or Compensatory Strategies

1) Approximation

Approximation is strategy that using alternative term which expresses the meaning of the target lexical item as closely as possible.

$\mathrm{T}$ : Before we open our study (approximation), please say basmallah together.

S : Bismillahirakhmanirrakhim

$\mathrm{T}$ : Good morning students

S : Morning, sir

2) Non-linguistic Means

Non-linguistic Means is strategy that is used by the learners when they cannot explain their intended meaning to the interlocutor or maybe they were missing the word.

T4 : They are sleeping!? Ok, emm.. have you remind emm.. what the material emm we have discuss yesterday?

$\mathrm{S}$ : Descriptive text

T4 : Are you sure?

$\mathrm{S}$ : yes,

T4 : Descriptive text (nodding her head) (Non linguistic means: gesture), an then emm what the purpose of descriptive text?

3) Restructuring

Restructuring is strategy which is abandon the execution of a verbal plan because of language difficulties, leaving the utterance unfinished, and communicating the intended message according to an alternative plan. 


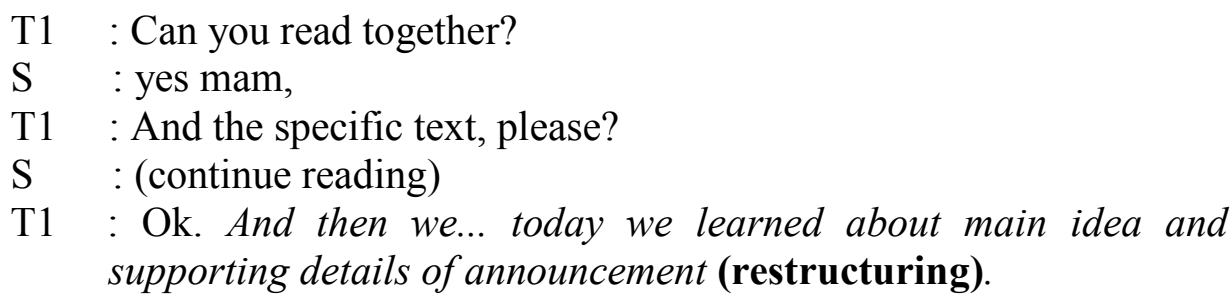

4) Literal Translation

Literal translation is strategy that is used by translating literally a lexical item, an idiom, a compound word or structure from L1/L3 to L2.

$$
\begin{aligned}
& \text { S : You! } \\
& \text { T2 : I will read for you again. Identification is part of descriptive text } \\
& \text { that contain of the topic what to be describe in descriptive } \\
& \text { text. You can read in the your heart. (Literal translation from L1) } \\
& \text { S : Finish, sir. }
\end{aligned}
$$

5) Retrieval

This is the strategy which is attempts to retrieve a lexical item saying a series of incomplete or wrong forms or structures before reaching the optimal form.

T4 : Bromo? So, you can (laugh) ok, Dwi, please describe about Bromo mountain to your friends.

$\mathrm{S} \quad$ : yes mam, (she is describing Bromo mountain)

T4 : So beautiful scenery. Ok, thank you, Dwi. Then, please open your book page sixty.. sixty nine. Sixty nine... sixty nine. After you find the word compare you answer to the class-classmate (retrieval) sitting next to you.

c. Stalling or Time-Gaining

1) Fillers, Hesitation devices and Gambit

a) Fillers

Fillers is strategy that is used to gain time in order to keep the communication channel open and maintain discourse at times of difficulty.

$\begin{array}{ll}\text { T2 } & \text { I will repeat again. Ok... eee.. what do you } \\ \text { think about descriptive? } & \\ \mathrm{S} & \text { : To describe something } \\ \mathrm{T} 2 & \text { : That is good answer.. ee... siapa... eee.. who is } \\ & \text { your name? (fillers) Oke thank you, your } \\ \text { answer is good. }\end{array}$

b) Gambit and hesitation Devices

Gambit is very similar to hesitation device in terms of the function. Both of them have the same function as the device that is used to fill in the gap between the utterances while the speakers are taking the time. 
T5 : Oke. I will emm.. show you the example of the narrative text. (hesitation) The Most Deer and the Crocodile. Have you ever read this story before?

$\mathrm{S} \quad$ : yes, sir

T5 : Yes. The Most Deer and the Crocodile. Emm.. and then what is the generic structure of the narrative text?

2) Self and Other Repetition (hesitation) You know? (gambit)

Self repetition is strategy that is used by repeating a word or a string of words immediately after they were said.

T1 : Nothing? Oh good-good (repetition). Students, do you know what is an announcement is?

S : No,

T1 : Well-well (repetition) I am going to read ee.. announcement and pay attention and listen carefully.

d. Self-Monitoring Strategies

1) Self-initiated Repair

Self-Initiated repair is strategy used by making self-initiated correction in one $e^{\text {ee }}$ own speech.

T7 : Ok, Invented. This is irregular or regular verb?

$\mathrm{S} \quad$ : Regular verb

T7 : Regular verb, ok, that's good. This is irregular verb. Emm, I'm sorry I mean this is emm regular verb. (Self-Initiated Repair)

2) Rephrasing

Rephrasing is strategy repeating a term, but not quite as it is, but by adding something or using paraphrase.

T18 : I wanna ask you about our ne the our material in the last week about ee about descriptive text. (repetition) Ee Yunita maybe? Ee descriptive text? (hesitation)

$\mathrm{S} \quad$ : Descriptive text is to describe thing and all opinion or to give information

T18 : oke great answer. Give applause for Yunita. And after we remembering about our lesson the last meeting. Oke we go to run about the type of letter, there is personal letter. Emm, anyone know what is personal letter in your in your opinion? (repetition) Can you explain in your word in your

e. Interactional Strategies own word? (self rephrasing)

1) Repetition Requests

Repetition requests occurred when the interlocutor does not hearing or understanding something properly. 
T10 : Present tense. Ok, good job. Then, here emm for today I have emm some picture for you. This is the picture. There are three picture here. Who know the first picture is?

S : Tornado

T10 : Tornado, right. This this is tornado. Can you repeat after me? (repetition requests). A tornado

2) Appeals for Help : A tornado

Appeals for help is strategy that is used by asking for their teacher, partner, or the other tools such as dictionary to complete the utterances they want to say.

\section{T16 : Any question}

so far? $\mathrm{S} \quad$ : No

T16 : No? Oke. Emm oke today we have learned about emm descriptive text (hesitation), and I would like to give some revew-some review (retrieval) about descriptive text. Emm descriptive text is the text that use in every life to describe object, people, animal, or etc (twisting her hands) (non linguistic means: gesture). And what is the language.. apa.. grammatical feature? (appeals for help: direct)

2 Table Frequency of Communication Strategies Used by Students

Table 1 Frequency of Each Types of Communication Strategies Used by Sixth Semester Students of Muhammadiyah University of Surakarta in 2015/2016

\begin{tabular}{|c|c|c|c|c|c|c|}
\hline No & $\begin{array}{c}\text { Types of } \\
\text { Communication } \\
\text { Strategies }\end{array}$ & $\begin{array}{c}\text { Subtypes of } \\
\text { Communication } \\
\text { Strategies }\end{array}$ & Frequency & $\begin{array}{l}\text { Percent. } \\
(\%)\end{array}$ & Total & $\begin{array}{l}\text { Total } \\
(\%)\end{array}$ \\
\hline \multirow[t]{2}{*}{1.} & \multirow{2}{*}{$\begin{array}{l}\text { Avoidance or } \\
\text { Reduction } \\
\text { Strategies }\end{array}$} & Topic Avoidance & 2 & $0,38 \%$ & \multirow[b]{2}{*}{3} & \multirow[b]{2}{*}{$0,57 \%$} \\
\hline & & $\begin{array}{l}\text { Message } \\
\text { Abandonment }\end{array}$ & 1 & $0,19 \%$ & & \\
\hline \multirow[t]{5}{*}{2.} & Achievement or & Approximation & 12 & $2,25 \%$ & 142 & $26,64 \%$ \\
\hline & \multirow[t]{4}{*}{$\begin{array}{l}\text { Compensatory } \\
\text { Strategies }\end{array}$} & $\begin{array}{l}\text { Non-linguistic } \\
\text { Means }\end{array}$ & 26 & $4,88 \%$ & & \\
\hline & & Restructuring & 24 & $4,50 \%$ & & \\
\hline & & $\begin{array}{l}\text { Literal } \\
\text { Translation }\end{array}$ & 17 & $3,19 \%$ & & \\
\hline & & Retrieval & 63 & $11,82 \%$ & & \\
\hline
\end{tabular}




\begin{tabular}{|c|c|c|c|c|c|c|}
\hline 3. & $\begin{array}{l}\text { Stalling or Time- } \\
\text { gaining } \\
\text { Strategies }\end{array}$ & $\begin{array}{l}\text { Filler, } \\
\text { Hesitation } \\
\text { Device and } \\
\text { Gambit, }\end{array}$ & 234 & $43,90 \%$ & \multirow[t]{2}{*}{373} & \multirow[t]{2}{*}{$69,98 \%$} \\
\hline & & $\begin{array}{l}\text { Self and Other } \\
\text { Repetition }\end{array}$ & 139 & $26,08 \%$ & & \\
\hline 4. & $\begin{array}{l}\text { Self-monitoring } \\
\text { Strategies }\end{array}$ & $\begin{array}{l}\text { Self-initiated } \\
\text { Repair }\end{array}$ & 4 & $0,75 \%$ & \multirow[t]{2}{*}{5} & \multirow[t]{2}{*}{$0,94 \%$} \\
\hline & & Rephrasing & 1 & $0,19 \%$ & & \\
\hline \multirow[t]{2}{*}{5.} & \multirow{2}{*}{$\begin{array}{l}\text { Interactional } \\
\text { Strategies }\end{array}$} & Appeals for Help & 1 & $0,19 \%$ & \multirow[b]{2}{*}{10} & \multirow[b]{2}{*}{$1,88 \%$} \\
\hline & & $\begin{array}{l}\text { Repetition } \\
\text { Request }\end{array}$ & 9 & $1,69 \%$ & & \\
\hline \multicolumn{3}{|c|}{ Total Strategies } & 533 & $100 \%$ & 533 & $100 \%$ \\
\hline
\end{tabular}

\section{The Dominant Types of Communication Strategies}

The dominant type of communication strategies used by sixth semester students of Microteaching class of English Education Department of Muhammadiyah University of Surakarta is Filler with 43,90\%, afterward Self and Other Repetition with 26,08\%, then followed by Retrieval with 11,82\%, and then Non- linguistic Means 4,88\%, Restructuring 4,50\%, Literal Translation 3,19\%, Approximation 2,25\%, Repetition Requests 1,69\%, Self-initiated repair 0,75\%, and Topic Avoidance 0,38\%. Nevertheless, Message Abandonment, Rephrasing, and Appeals for Help becomes the lowest with the same number percentage, that is $0,19 \%$. The conclusion of summarizes the data is the dominant type which is used by sixth semester students of Microteaching class of English Education Department in Muhammadiyah University of Surakarta is is Fillers with $43,90 \%$, and the type of communication strategy which rarely used by the students are Message Abandonment, Rephrasing, and Appeals for Help with 0,19\%.

\section{Discussion}

Here, the writer will describe the result of the finding and the comparison between this study and the previous studies. In this research, the writer uses Celce Murcia framework for analyze the data. Based on the research finding there are 3 research questions that are discussed. First, the types of communication strategies used by students. Second, the frequency of each type communication strategies used by students. Third, the 
dominant type of communication strategies used by the students. The writer found five types and thirteen subtypes of communication strategies from the data analysis. They were, a) Avoidance and Reduction Strategies: (1) Topic Avoidance with 0,38\%, (2) Message Abandonment $0,19 \%$, b) Achievement and Compensatory Strategies: (1) Approximation 2,25\%, (2) Non- linguistic Means 4,88\%, (3) Restructuring 4,50\%, (4) Literal Translation 3,19\%, (5) Retrieval 11,82\%, c) Stalling and Time-Gaining: (1) Fillers, Hesitation devices, and Gambits with 43,90\%, (2) Self and Other Repetition with 26,08\%, d) Self-Monitoring Strategies: (1) Self-initiated repair 0,75\%, (2) Rephrasing 0,19\%, e) Interactional Strategies: (1) Appeals for Help with 0,19\%, (2) Repetition Requests with 1,69\%. Based on the data that have been analyzed, the writer found that the dominant types of communication strategy used by students in microteaching class is fillers, hesitation devices, and gambit. Based on the data, the students used those strategy appropriate with Celce-Murcia ${ }^{e e}$ theory, which means the students used those strategy to gain the time while they are remembering what the next sentence they want to say. This situation also found in the previous study where the learners of foreign language use this kind of strategy to keep the conversation going on. In other case, the lowest percentage of communication strategy are message abandonment, rephrasing, and appeals for help. The writer only found one (1) utterance of message abandonment, two (2) utterances of rephrasing, and one (1) utterances of appeals for help. Yet, the students used those strategy in appropriate situation. Celce Murciaes taxonomy states that message abandonment used when the speaker did not know what to say next, then they decided to give up and did not continue their speech. It is appropriate with the finding that has been found by the writer. Rephrasing is strategy used by the students when they are aware of the mistakes they made in the sentence, then they correct it by adding something or paraphrase. The writer also found this strategy used by the student, it is also appropriate with the theory of Celce-Murcia. The students that use appeals for help is also appropriate with the theory of Celce-Murcia that state appeals for help is strategy used by asking the lecturer, friend, or other tools like dictionary to complete their sentence. Those strategy also found in the previous study, which means that this study in line with the previous.

The next of communication strategy is approximation. The students in microteaching class used approximation when they producing a new word, approximately with the intended meaning. It is occured because of the students lack of vocabulary, so when they got a word that has similar meaning with their intended meaning, they just keep speaking. It is appropriate with Celce-Murciaes taxonomy. This strategy is found in one previous study 
that has been conducted by Pratiwi in 2011. Non linguistic-means is also founded by the writer in her research. The students used non linguistic-means when they can not say their intended meaning, so they express their meaning by using miming, gesture, or facial expression. Celce- Murcia ${ }^{e e}$ s framework define this strategy as non-verbal action to replace a lexical item. The students in microteaching class used this strategy match with the theory of Celce-Murcia. This strategy found in three previous study. Thus, this study in line with the three previous study.

The students in microteaching class is also use restructuring. The students in microteaching used restructuring when the speaker or the student rearange the structure of the sentence because of they hesitate with the structure before. Hence, they looking for an appropriate sentence to say their intended meaning. It matches with the theory of CelceMurcia. This strategy found in three previous study. Thus, this study in line with the three previous study. In other case, some students also use literal translation match with the theory of Celce-Murcia which means they use this strategy when they are literally translated the sentence or idiom from L1 into L2. The writer found seventeen (17) utterances of literal translation in microteaching class. This strategy only found in one of previos study which conducted by Pratiwi in 2011. The last strategy which is belongs to achievement or compensatory strategy is retrieval. Retrieval is generally used when the student facing a difficulty to pronounce a word. The students in microteaching class also used this strategy when they got difficulty to pronounce a word, so they repeated until they found the right one, appropriate with Celce-Murcia theory. In previous study, the writer only found this strategy in one previous study, which means this strategy in line with the previous. Self and other repetition is strategy by repeating a word or the sentence in order to emphasizing their intended meaning or it just unconsciously repeatition. The students in microteaching used this strategy when they hesitate with what they say, but most of them used this strategy in unconsciously. It match with Celce- Murcia taxonomy which means this strategy use by repeating some words or phrases. This situation has been found in the third previous study. The next strategy of communication is self-initiated repair. It is strategy that is use by student when they are speaking but they aware that they made a mistake in their sentences, so they fix it by making a new one. The students in microteaching class used this strategy appropriate with Celce-Murcia theory. They aware of the mistake they made, so they can fix it by their own selves. This situation also found in three previous study. Thus, this study in line with the three previous study.

The last strategy is repetition requests. Based on Celce-Murciaes theory, repetition 
requests occured when the interlocutor does not hear or understand something properly. Hence, the interlocutor asking for repetition. The students in microteaching class used this strategy appropriate with the theory of Celce- Murcia. Yet, this strategy not popular enough in microteaching. The writer only found 9 utterances with total number 1,69\%. This strategy only found in one previous study. The reason why the writer choose Celce Murcia framework as her theory to analyzed the data is because this is the newest theory. Further, this theory is broader than other. It is more complete with more subtypes, thus the writer who wants to analyze is easier. Here, the writer also agreed with theory of Celce Murcia.

\section{Conclusion}

The writer would like to draw the conclusion based on the data analyzed. The result of communication strategy used by sixth semester students in Microteaching class of English Education Department are as follows: In microteaching class, the speaking ability of the students is sufficient. However, their speaking is still developing. Here, communication strategies have a role to helps the students live on the conversation when they are hesitate because of worried of mistaken or even lack of vocabulary. The writer found some factors why the students in sixth semester do those communication strategies in Microteaching. First, the writer guess that the students lack of vocabulary, since English is not their daily language. Second, the students has no enough confident to speak English. The writer summarizes the result of the types of communication strategies with the percentage. The highest is Filler with $43,90 \%$, afterward Self and other Repetition with $26,08 \%$, then followed by Retrieval with $11,82 \%$, and then Non- linguistic Means $4.88 \%$, Restructuring 4,50\%, Literal Translation 3,19\%, Approximation 2,25\%, Repetition Requests 1,69\%, Self-initiated Repair 0,75\%, and Topic Avoidance 0,38\%. Message Abandonment, Rephrasing, and Appeals for Help placed in the lowest number or rarely used with each percentage is $0,19 \%$. From the summarizes the data above, the writer would like to give conclusion that the types of communication strategies which often used by the students is Filler with the percentage 43,90\%. Filler is the easiest types that usually come out spontaneously whenever the students have a talk, even in Bahasa. And then the types which rarely used by the students in Microteaching Class of English Education Department of Muhammadiyah University of Surakarta is Message Abandonment, Rephrasing, and Appeals for Help with the percentage 0,19\%. 


\section{Acknowledgement}

This research is dedicated to her forever beloved father M. Bahrun, her mother Endang Murbani, and her lovely brother Rendi Elyas Binarfi.

\section{Bibliography}

Bagaric, Vesna, and Djigunovic, Jelena Mihaljevic. 2007. Defining Communicative Competence. Review Paper. Metodika, 8/94-103. Brink, H. I. (1993). Validity and reliability in qualitative research. Curationis, 16(2), 35-38.

Canale, M. \& Swain, M. 1980. Theoretical bases of communicative competence approaches to second language teaching and testing. Applied linguistics, 1, 1- 47.

Celce-Murcia, M., Dornyei, Z, and Thurell, S. 1995. "Communicative Competence: A pedagogically Motivated Model with Content Specifications. ”Applied Linguistics, 6/2:5-35.

Delamere, Brigid. 1998. Communication strategies of English-speaking Learner of French on a Business Studies Course, PhD dissertation. School of Applied Language Interlocutor Studies. Dublin City University. Ireland.

Faerch, C. \& Kasper, G. 1983. Strategies in interlanguage communication. London: Longman.

Fauziati, Endang. 2010. Teaching English as Foreign Language II (TEFL II). Surakarta: Era Pustaka Utama.

Fauziati, Endang. 2009. Readings on Applied Linguistics: A handbook for Language Teacher and Teacher Researcher. Surakarta: Era Pustaka Utama.

Golafshani, N. (2003). Understanding Reliability and Validity in Qualitative Research. Journal of Technology Education, 8(4), 597-606. http://doi.org/10.1111/j.14754762.2010.00954.x

Herawati, Oktavia. 2015. Communication Strategies Used by the Eight Grade Students of SMP $N 1$ Surakarta in Developing Speaking Skill.Unpublished Research Paper: Surakarta: Muhammadiyah University Press.

Hymes, D. 1972. "On Communicative Competence". In J.B Pride and J. Holmes (Eds.), Sociolinguistics pp. 269-93”.

Harmondsworth: Penguin. Pratiwi, Fitri Endah. 2011. Communication Strategies Used by English Department Students of UMS in Speaking Class. Unpublished Research Paper: Surakarta: Muhammadiyah University Press. 
Rolitasari, Aisyah. 2015. Communication Strategy Used by University of Surakarta: A Case study in Saturday English Gathering (SEGA) program. Unpublished Research Paper: Surakarta: Muhammadiyah University Press.

Sari, Ambar Ratna. 2015. Strategies in Communication Ued by English Department Students in Muhammadiyah University of Surakarta: A Case Study in Saturday English Gathering (SEGA) program. Unpublished Research Paper: Surakarta: Muhammadiyah University Press.

Savignon. J. Sandra. 1983. Communicative Competence: Theory and Classroom Practice: Text and Contexts in Second Language Learning. USA: Addison- Wesley Publishing.

Selinker, Larry. 1977. Interlanguage. In Fauziati, Endang. 2010. Teaching English as a Foreign Language (TEFL). Surakarta: Era Pustaka Utama.

Tarone, E. 1981. Communication Strategies: Foreigner Talk and Repair in Intercommunication. TESOL Quarterly, 9: 417 - 431.

Yano, Yasukata. 2003. Communicative Competence and English as an International Language. Published Research Paper. Waseda University. 